\title{
THE INTERNATIONAL NOTIFICATION OF INFECTIOUS DISEASES.
}

\author{
By EDWARD WALFORD, MC.D., D.P.II., \\ Medical Officer of Italth, City und Pont Semitury I listrict of Cardifi.
}

(FELLOW.)

\begin{abstract}
ATHOUGH the subject of Internatimal Notification undoubtedly A concerns inland towns, I shall confine inyself chiefly to that part of it which is most closely related to port sanitary adninistration, and shall refer more particularly to smallpox, as one of the most important of the ordinary infectious diseases with which we have to deal.
\end{abstract}

All the ports in this country aro more or less subject to the invasion of smallpox. The infection may be introduced by persons of our own nationality, or by aliens. Many of the extensive outhreaks of recent. years in large towns owe their origin to invasions from abroal. The recent epidemics in London, Liverponl, and in some other places, were due, I believe, in the first instance to infection brought from forcign countries. All of us who are engagerl in the public health service thoroughly appreciate the value of those weekly returns of the Local Goverument Board containing the records of the notification of infectious discases in each sanitary district in the United Kingdom. They indicate at a slance the local incidence of clisease, and in many cases the direction of an epidemic wave. Of the utmost value also are the prompt warnings from our colleagues of the possible danger to be apprehended from persons who have been exposed to infection, and who are proceeding to our district. But a shipload of such contacts may at any time come into any port without the slightest warning from abroad.

The danger of such an occurrence is sufficiently obvious, as, however vigilant the medical inspection at a port may bc, it is marle usually under somewhat unfavourable conditions, and a timely warning of what to expect would often prove an invaluable aid to diagnusis. Those of us who have had to examine Liscars or coloured men covered with coal dust and 
dirt, and lying in a bally-lighted forecastle, will readily appreciate the difficulty of making a diagnosis in a case of smallpox in its early stage or in a modified form. For many years past $I$ have felt that some syotem of international communication, more reliable than the official bill of health, would be a useful addition to our present methods.

The following recent event came to my knowledge through the courtesy of the medical officer of health of one of the largest ports in this country. A member of the crew of a steamer entering this port contracted smallpox on board, and on being paid off, went to his lome in the North, then to the local infirmary, and was there found to be suffering from that disease. The infection in this case was derived from Spain. No notice was taken of the illness during the royage, no mention wits marle of it in the log-book, and the captain disclimed, of course, all knowledge of it. Thanks to the information received from the medical officer of health, I was on the look out for this ressel when she arrived in Carcliff; but how much more sitisfactory would it have been if an intimation had been sent in the first instance from the port of cleparture in Spain.

At a conference held in London in 1!)(1, relating to the spreal of infectious diseases by vagrants, the following resolution was submitted: "This Conference is of opinion that the Port Sanitary Authoritiess should be authorised to take more stringent precautions to prevent the landing of persons arriving by vessels at the ports, who are suffering from smallpox, or who have been exposed to the infection of that disease, and for this purpose this Conference suggrests that the regulations as to choleria, jellow fever, and plague, made by the Local Government Board on the 9th November, 1896, should be extended to smallpox." This resolution wals not alopted in the form in which it was submitted. An amendment was moved and calrried, omitting all mention of the Local Government Board regulations, which are not suitable for this purpose. Oljection might be raised also to the wording of other parts of the resolution. Fur instance, smallpox patients must as a rule be landed, and also those who have been exposed to infection; the former for isolation and treatment, the latter for observation. The resolution is chiefly valualle as an expression of opinion of the conference that port sanitary anthorities should have greater jowers than at present. As a rule, however, little comes of these pious opinions, and pending the arrival of those greater powers, I would sulmit that an improvement in the methorls of our International Intelligence Department might with advantinge be attempted. 
A vision of international notification seems to have floated before the eyes of the International Sanitary Congress held in Parris in 1903. From the report of the British delegates it would appear that at the first International Congress held in Vienna in 1874, there was a proposal to establish a central office under international management, and to collect and publish informintion on the course of epidemic discases all the world over. This proposal was never carried out, but it was reviver in a morlified form ly- France at the conference of 1903. M. Barrère, who introduced the proposal, was careful to state that the bureau would be strictly international, that wherever located, the local govermment should exercise no controllingr influence over it, that its main object would be to collect and distribute information alout ejidemics and the measures taken to) deal with them.

The following resolutions (contained in the appendix to the report) were passed by the commission of ways and means of the Sanitary Conference of Paris, regarding an international health office:-

1. In international health office shall be established on the lines followed in the institution and conduct of the Intemational Office of Weights anll Measures. It shall have its seat in Paris.

2. The international office shall fulfil the function of collecting information as to the progress of infectious diseases. To this end it shall receive information given to it by the chief health authorities of the States that are parties to it.

3. The 'office shall periodically set out the results of these labours in official reports, which shall be communicated to the "ontracting governments. These reports must be made public.

4. The office shall be supported by contributions from the contracting govermments.

5. The government, in whose country the international office is to be established, shall be charged with the submission, within three months of the signing of the proceedings of the conference, for the approval of the contracting States, of regulations for the institution and concluct of that office.

Article 181 of the Paris Convention refers to these resolutions as follows:- "The conference having taken note of the resolutions hereto appended, passed by its commission of ways and means, regarding the creation of an international health office in Paris, the French government shall, at such time as it may think fit, submit by diplomatic channels, proposils on this subject to the States represented at the conference." 


\section{The Internutional Notificution of Infectious Diseases.}

The British delegates to the Paris Convention seem to have thrown : fair amount of cold water over this proposal. They report that, while from a thenretical standpoint this proposed institution had not a little to recommend it, there were important prictical considerations which prevented them from giving it immediate and umescrved acceptance. They state that so far as concerns the obtaining of information on the course of epidemics, the machinery already possessed by His Majesty's Government for the purjose is as efficient as, if not more efticient than, any machinery that could be set up by an international bureau. It is doubtful, they think, if the reports from the bureau would be any more complete than those published by the Local Goremonent Boird, and that so far as the United Ringrdom was concerned, the propersed bureau seemed to offer no advantage that she does not already possess.

The French delegates, on the other hand, seem to have attached much importance to the proposal. One does not quite know the real reason for the objection on the part of the British delegates.

There are, of course, difficulties in the way. Sanitary administration abroad is more a police affair than with us, and pussibly the information obtained might have to filter through the hands of an army of officials before issuing from the bureau. In these days of rapid telegraphic and telephonic communieation there need not surely be delay in the notification of a clisease to a central bureau from any of the large towns and ports in Europe, from whence the information conld te despatched as required.

No international arrangement could, of course, be come to with those countries in which antiquated systems of quarantine are carried out, and costly and useles: restrictions are placed upon the movements of vessels. In such cases the notification of a case of smallpox in :an English port might be the means of inflicting enormous loss upon the unfortunate owner of a vessel sitiling from such port, yuite out of all proportion to any possible adrantage or gatin to anyone.

A few words as to un present methods of obtaining information of infections sickness on boarl ressels, and in this connection it must be remembered that, although on paper and in theory, cases of infectious disease on boild ships and in houses are dealt with in the same way, in practice this is not altugether the case. Persons suffering from small pox on land usually fall sooner or later into the hands of a medical practitioner. They find their way into the casual warls of workhouse's, into infirmaries, into common lodgring houses, and into places where medical attendance is at hand. On buard ship, unless there is a doctor on board, such persons are more likely to escalle detection. The Infectious Disease (Notification) 
Act may be in force, lout unles: a doctor is called in, this Act is not of much service. The regulations under Section 125 of the Public Health Act, $1 \times 75$, place the responsibility of notifying infections disease upen the master or person in chirge of the vessel, on entering port: but at conviction for neglecting to notify is seldom possible, as the mater pleads ignorance aud want of liagnostic skill. Evasion of this responsibility are extremely common, much more so than is usually supposecl.

Customs officer: boarding ressels from abroad notify to the sanitary authority any case of infections disease which they may detect, but of course they are not very likely to detect anythiug of the kind unless their attention is called to it. A system of inter-communication between the various ports would undoubtedly be the means of reducing the number of these evasions; the master would feel that it was nseless to practice deception when the anthorities of the port of arrival might he already in possession of the facts. In many cases, of course, the master of the ship is not aware of the actual existence of at case of infections discase at the time of arrival in port, but the information which we might expect from the port of departure would be an intimation of exposure to infection on the part of persons on board, and an indication that a carreful medical inspection of such persons was called for.

It may be said that sur system of medical inspection is not of muclr value if we cannot detect case's of infectious disease on board ships coming into our ports unless we hat ve had previous warning arousing our suspicions. Many sucl ${ }_{1}$ cases are, of course, detected, but I would remind you that the medical inspection of persons arriving at our shores on vessels exists only in any degree of completeness at our large seaports, that in the majority of ports it is unknown, that it is not compulsory by law, except in reference to the introduction of cholera, yellow fever, or plagne, and that even when it exists it must of necessity be carried out under unfarourable conditions. as to time, jlace. light, surroundings, etc.

Somc notification, therefore, from the port of departure, in the case of vessels infected during any part of their voyage, would be of extreme value to the authorities of the port of arrival. and a useful supplement to the system of medical inspection, however efficient that miglit be.

In conclusion. I would suggest that international notification might be considereel from two peints of view. The primary object would be the concentration in a central intermational health office of all arailable information concerning epidemic cliseases occurring in the countries entering into the convention. and the distribution of this information to the several countries concerned, very much on the lines of the arrange-

voL. xxriI. Yo. 8. 
ment now so satisfacturily arried out by the Local Government Board in this conntry. I am inclined to think that information so distributed would have an official stamp upon it, and would be altogrether more reliable than that which is derived from paragraphs in newspapers, a source of information recommended in a recent circular letter of the Lucal Government Buarl, relating to plague, in the following terms:-

"It will be seen . . . . That the Olficers of Customs will look to the Medical Oflicer of Health to inform them from time to time of any particular ports or countries. the ressels alriving from which the Medical Officer may desire to risit. and in this connection the Board would observe that the earliest infurmation which would usually he avaliable to this end is that which would be obtalined hy a rogular examination of the news telegraphed from abroad for the purposis of the Daily Press."

The responsibility, therefore, of determining which are infected ports rests upon the modical officer of health, who is expecterl to be a diligent realler of the chaily papers. The Local Gorernment Boaril, although always ready to assist and to mive information and grond adrice, takes no responsibility in this matter. It is obvions that in the event of any obstruction to the ufficess carrying out the pligue regulations, a newspaper" paragraph would be an insecure basis mon which to found a prosecution. Information from an international burcau would be preforable.

The other aspect of interuational notification might assume more the shape of a prompt and fairly emmplete intelligence department letween the countries concerned, having for its chief object the continued nbservation "1. medical inspection of persons who have been exposed to infection. It the present time medical officers of health are in the labit of forwarling to their collengrues lists of names and aldresices, and the supposed rlestination of such persons, in wrer that they may be kept under observation mutil the expiration of the incubation period. Silch a rstem night, without any great ditiveulty, be made international in its operation. Certainly the difficulty would not he insurmountable in the arse of persons exposed to infection and forming members of the crew or passengers of a ship. It would in must cases be sufficient to indicate the name of the discase, the name of the ship, and the purt for which it was busund.

[For Discussion in this Puper see paye t11.] 